\title{
An efficient process for dehydration of xylose to furfural catalyzed by inorganic salts in water/dimethyl sulfoxide system
}

\author{
Wenju Wang a , Huiling Li a , Junli Ren a,*, Runcang Sun a,b, Jie Zheng c, Guangwei Sun c, Shijie Liu a,\# \\ a State Key Laboratory of Pulp and Paper Engineering, South China University of Technology, Guangzhou 510640, Guangdong, China \\ b Institute of Biomass Chemistry and Technology, Beijing Forestry University, Beijing 100083, China \\ c Liaoning Key Laboratory of Pulp and Paper Engineering, Dalian Polytechnic University, Dalian 116034, Liaoning, China
}

\section{A R T I C L E I N F O}

Article history:

Received 7 January 2014

Accepted 13 January 2014

Published 20 May 2014

\section{Keywords:}

Xylose

Furfural

Inorganic salt

Stannic chloride

Lithium chloride

Dimethyl sulfoxide

\begin{abstract}
A B S T R A C T
An efficient homogeneous catalytic process was developed for the dehydration of xylose to furfural using inorganic salts as catalysts in a water/dimethyl sulfoxide (DMSO) system under mild condition. The effects of the types of inorganic salts were compared. The results showed that chlorides had higher catalytic performance than other salts, and $\mathrm{SnCl}_{4}$ was the most effective chloride. The catalytic activity of paired $\mathrm{SnCl}_{4} / \mathrm{LiCl}$ catalysts was much higher than that of the single salt, and when the distribution coefficient $\left(\chi_{\mathrm{SnCl} / 4}\right)$ was 0.8 , the maximum furfural yield was $56.9 \%$. The effects of the reaction conditions on the furfural yield were also investigated. The highest furfural yield, $63.0 \%$, was achieved at $130^{\circ} \mathrm{C}$ for $6 \mathrm{~h}$ under the optimized reaction conditions.
\end{abstract}

(C) 2014, Dalian Institute of Chemical Physics, Chinese Academy of Sciences. Published by Elsevier B.V. All rights reserved.

droxymethylfurfural (HMF), and levulinic acid [4-6]. However, because of the complex hemicellulose structure, there are relatively few studies on hemicellulose conversion to fuels and chemicals. Hemicelluloses can be used as feedstocks to produce many important chemicals such as furfural, furfuryl alcohol, furan, and tetrahydrofuran. The long-term goal should therefore be focused on exploring promising routes for hemicellulose transformation into valued-added chemicals.

Furfural, which has a wide range of application in the oil-refining, plastics, pharmaceutical, and agrochemical industries, has been identified as one of the key "green" chemicals produced from pentose-based hemicelluloses, with an annual

\footnotetext{
* Corresponding author. Tel: +86-20-87112009; Fax: +86-20-87111861; E-mail: renjunli@scut.edu.cn

\# Corresponding author. Tel/Fax: +86-20-87111861; E-mail: sliu@esf.edu

This work was supported by Guangdong Natural Science Funds for Distinguished Young Scholar (S20120011250), Program for New Century Excellent Talents in University (NCET-12-0194), Foundation for the Author of National Excellent Doctoral Dissertation of China (201169), Science and Technology Project of Guangdong Province (2011B050400015), and the Fundamental Research Funds for the Central Universities (2014ZG0003), South China University of Technology.
}

DOI: 10.1016/S1872-2067(14)60031-0 | http://www.sciencedirect.com/science/journal/18722067 | Chin. J. Catal., Vol. 35, No. 5, May 2014 
global output of 700000 t [7,8]. Furfural can be further transformed to furfuryl alcohol and other five-membered oxygen-containing heterocycles such as furan and tetrahydrofuran [9]. Furfural and its derivatives are also used to make jet- and diesel-fuel-range alkanes, as a gasoline blendstock, and to develop the next generation of biofuels and bioplastics [10].

Hemicellulose conversion to furfural involves acid-catalyzed hydrolysis of polysaccharides to the constituent monosaccharides, mainly D-xylose, and dehydration of xylose to furfural [11]. Mineral acids, particularly sulfuric acid, are used as catalysts in traditional processes for furfural production, and these processes are accompanied by serious equipment corrosion, acidic waste stream production, and high energy consumption. It is necessary to consider the environmental impacts and energy requirements as well as economic factors. New ecofriendly and efficient processes for furfural production that achieve the same yields under significantly milder conditions to minimize the carbon footprint are therefore urgently needed [12].

Inorganic salts, particularly metal chlorides, have been proven to have an important influence on the conversion of lignocellulosic biomass to furans [1] and on the dehydration of glucose and fructose to HMF [13] in ionic liquids under microwave irradiation. A single-step conversion of cellulose to HMF using a pair of metal chlorides $\left(\mathrm{CuCl}_{2}\right.$ and $\left.\mathrm{CrCl}_{2}\right)$ as catalysts in an ionic liquid was developed by Su et al. [14]. $\mathrm{Zr}(0) \mathrm{Cl}_{2} / \mathrm{CrCl}_{3}$ was found to be an effective catalyst for the conversion of cellulose and sugarcane bagasse to HMF and 5-ethoxymethyl2 -furfural in $\mathrm{N}, \mathrm{N}$-dimethylacetamide (DMA)/LiCl solvent under microwave-assisted heating [15]. Liu et al. [16] reported that $\mathrm{NH}_{4} \mathrm{Cl}$ salts could promote the conversion of D-fructose to HMF in isopropanol in $68 \%$ yield. However, there have been relatively few studies of the conversion of xylose or xylan to furfural using inorganic salts alone as catalysts. Zhang et al. [1] showed that using $\mathrm{CrCl}_{3}$ as a catalyst in ionic liquids led to a furfural yield of $63 \%$ from xylan under microwave-assisted heating at $\sim 200{ }^{\circ} \mathrm{C} . \mathrm{AlCl}_{3}$ and mineral acids were used as catalysts for the conversion of xylan in an ionic liquid and resulted in a maximum furfural yield of $84.8 \%$ at $170{ }^{\circ} \mathrm{C}$ under microwave irradiation [7]. Although ionic liquids, which have low vapor pressure and good thermal stability, are the preferred solvents for furfural production, their high viscosity and costs limit their industrial application. The use of microwave irradiation and high temperatures increases the energy consumption. Biphasic systems have been used to increase the furfural yield and inhibit the formation of by-products because the organic phase can continually extract furfural from the aqueous phase, so the selectivity is improved. vom Stein et al. [17] reported a catalytic conversion of xylose using $\mathrm{FeCl}_{3} / \mathrm{NaCl}$ as catalysts in a biphasic system consisting of an aqueous phase and a 2-methyltetrahydrofuran phase, achieving a maximum furfural yield of $71 \%$ at $140{ }^{\circ} \mathrm{C}$. $\mathrm{AlCl}_{3} \cdot 6 \mathrm{H}_{2} \mathrm{O}$ has also been used as a catalyst for the conversion of xylose in an $\mathrm{H}_{2} \mathrm{O}$ /tetrahydrofuran system at $140{ }^{\circ} \mathrm{C}$, giving $75 \%$ of furfural yield [18]. However, biphasic systems require large volumes of extracting solvents, making them less attractive and possibly uneconomical on an industrial scale [19].
Water, which is the most benign solvent and therefore ideal for green and sustainable chemistry, is a poor solvent for the dehydration of xylose because many by-products are formed during furfural production, leading to low selectivity. Dimethyl sulfoxide (DMSO) with low toxicity was used as a cosolvent to suppress undesired side reactions in the aqueous phase in the conversion of fructose to HMF $[19,20]$. In this work, we developed an efficient and environmentally friendly process for the dehydration of xylose to furfural using inorganic salts as catalysts in a homogeneous $\mathrm{H}_{2} \mathrm{O}$ /DMSO system at low temperature. The effects of the types of inorganic salts and the reaction conditions on furfural yields were compared.

\section{Experimental}

\subsection{Materials}

D-(+)-xylose (98\%) was purchased from the Adamas Reagent Co., Ltd. and used without further purification. $\mathrm{AlCl}_{3} \cdot 6 \mathrm{H}_{2} \mathrm{O}$, $\mathrm{MgCl}_{2} \cdot 6 \mathrm{H}_{2} \mathrm{O}, \mathrm{NH}_{4} \mathrm{NO}_{3}$, and $\mathrm{ZnCl}_{2}$ were supplied by the Guangzhou Chemical Reagent Factory (Guangzhou, China). $\mathrm{SnCl}_{4} \cdot 5 \mathrm{H}_{2} \mathrm{O}, \mathrm{KCl}$, and DMSO were obtained from the Lingfeng Chemical Reagent Co., Ltd. (Shanghai, China). $\mathrm{CrCl}_{3}$ and $\mathrm{LiCl}$ were purchased from the Tianjin Kermel Chemical Co., Ltd. (Tianjin, China). $\mathrm{CrCl}_{2}$ and $\mathrm{LaCl}_{3} \cdot \mathrm{H}_{2} \mathrm{O}$ were obtained from the Aladdin Chemistry Co., Ltd. (Shanghai, China). $\mathrm{FeCl}_{3} \cdot 6 \mathrm{H}_{2} \mathrm{O}$, $\mathrm{NH}_{4} \mathrm{Cl}$, $\left(\mathrm{NH}_{4}\right)_{2} \mathrm{SO}_{4}$, and $\mathrm{CaCl}_{2}$ were supplied by the Chengdu Kelong Chemical Co., Ltd. (Chengdu, China). $\mathrm{FeCl}_{2} \cdot 4 \mathrm{H}_{2} \mathrm{O}$, $\mathrm{CuCl}_{2} \cdot 2 \mathrm{H}_{2} \mathrm{O}, \mathrm{Fe}_{2}\left(\mathrm{SO}_{4}\right)_{3}, \mathrm{Fe}\left(\mathrm{NO}_{3}\right)_{3} \cdot 9 \mathrm{H}_{2} \mathrm{O}$, and $\mathrm{Al}\left(\mathrm{NO}_{3}\right)_{3} \cdot 9 \mathrm{H}_{2} \mathrm{O}$ were purchased from the Tianjin Damao Chemical Co., Ltd. (Tianjin, China). $\mathrm{Al}_{2}\left(\mathrm{SO}_{4}\right)_{3}$ was supplied by the Tianjin Fuchen Chemical Co., Ltd. (Tianjin, China). $\mathrm{CoCl}_{2}$ was obtained from the Tianjin Yongda Chemical Co., Ltd. (Tianjin, China). $\mathrm{MnCl}_{2} \cdot 4 \mathrm{H}_{2} \mathrm{O}$ and $\mathrm{NiCl}_{2} \cdot 6 \mathrm{H}_{2} \mathrm{O}$ were obtained from the Zhanyun Chemical Reagent Co., Ltd. (Shanghai, China). $\mathrm{NaCl}$ and $\mathrm{Cr}\left(\mathrm{NO}_{3}\right)_{3} \cdot 9 \mathrm{H}_{2} \mathrm{O}$ were purchased from the Guangzhou Jinhuada Chemical Reagent Co., Ltd. (Guangzhou, China).

\subsection{Typical procedure for dehydration of xylose to furfural using inorganic salts}

A typical experiment was carried out as follows. Xylose $[0.5$ g) and a certain amount of inorganic salt were poured into a thick-walled pressure vessel. After addition of $\mathrm{H}_{2} \mathrm{O}(2.5 \mathrm{~mL})$ and DMSO $(2.5 \mathrm{~mL})$, the sealed vessel containing the reaction mixture was immersed in a preheated thermostated oil bath, with a stirring rate of $500 \mathrm{r} / \mathrm{min}$. Xylose dehydration was performed at a preset temperature of $140{ }^{\circ} \mathrm{C}$ for $4 \mathrm{~h}$. The reactor was then cooled to room temperature and the mixture was filtered using a $0.22 \mu \mathrm{m}$ filter membrane for analysis. All experiments were replicated at least three times.

\subsection{Determination of xylose conversion and furfural yield}

The products were examined using gas chromatography-mass spectrometry (GC-MS) and identified using the NIST 08 MS library (Agilent 7890/5795 spectrometer; capillary 
column: Agilent DB-5, $30 \mathrm{~m} \times 0.25 \mathrm{~mm} \times 0.25 \mu \mathrm{m}$; programmed oven temperature: $60^{\circ} \mathrm{C}$, held for $3 \mathrm{~min}$, ramped to $280{ }^{\circ} \mathrm{C}$ at 8 ${ }^{\circ} \mathrm{C} / \mathrm{min}$, held for $15 \mathrm{~min}$; kept at $280{ }^{\circ} \mathrm{C}$ in split mode with a split ratio of $1: 1$; He carrier gas). The furfural content was determined using a high-performance liquid chromatograph (Agilent 1100) with a diode array detector at $277 \mathrm{~nm}$, and an Agilent Eclipse XDB-C18 column. The samples were injected with a $20 \mu \mathrm{L}$ loop, the column oven temperature was $30^{\circ} \mathrm{C}$, and the mobile phase was acetonitrile $/ \mathrm{H}_{2} \mathrm{O}(15 / 85, V / V)$ at a flow rate of $1 \mathrm{~mL} / \mathrm{min}$.

Xylose was determined using a GPC system (Waters 2414) with a refractive index detector and a Bio-Rad organic acid column (Aminex HPX-87H, $300 \mathrm{~mm} \times 7.8 \mathrm{~mm}$ ) with $\mathrm{H}_{2} \mathrm{SO}_{4}(5$ $\mathrm{mmol} / \mathrm{L}$ ) at a flow rate of $0.5 \mathrm{~mL} / \mathrm{min}$ as the mobile phase.

The xylose conversion and furfural yield were defined as follows:

Xylose conversion $=($ moles of $x y l o s e$ reacted $) /($ moles of initiate xylose) $\times 100 \%$

Furfural yield $=($ moles of furfural produced $) /($ moles of initiate xylose) $\times 100 \%$

Furfural selectivity $=($ moles of furfural produced $) /($ moles of xylose reacted) $\times 100 \%$

\section{Results and discussion}

\subsection{Influence of inorganic salts on dehydration of xylose to furfural}

The effects of the anions in salt catalysts on the dehydration of xylose to furfural were determined by performing experiments using chlorides, sulfates, and nitrates of $\mathrm{Al}^{3+}, \mathrm{Fe}^{3+}$, and $\mathrm{NH}_{4}+$ as catalysts. As shown in Fig. 1, metal chlorides such as $\mathrm{AlCl}_{3}$ and $\mathrm{FeCl}_{3}$ had significantly higher catalytic performance than sulfates and nitrates for furfural production under the same reaction conditions. The maximum furfural yield of $40.6 \%$ with $40.7 \%$ of selectivity was achieved over $\mathrm{AlCl}_{3}$. These results show that chlorides contributed to the dehydration of xylose to furfural. In the 1950s, Dunlop et al. [21] found that chlorides were conducive to the separation of furfural during

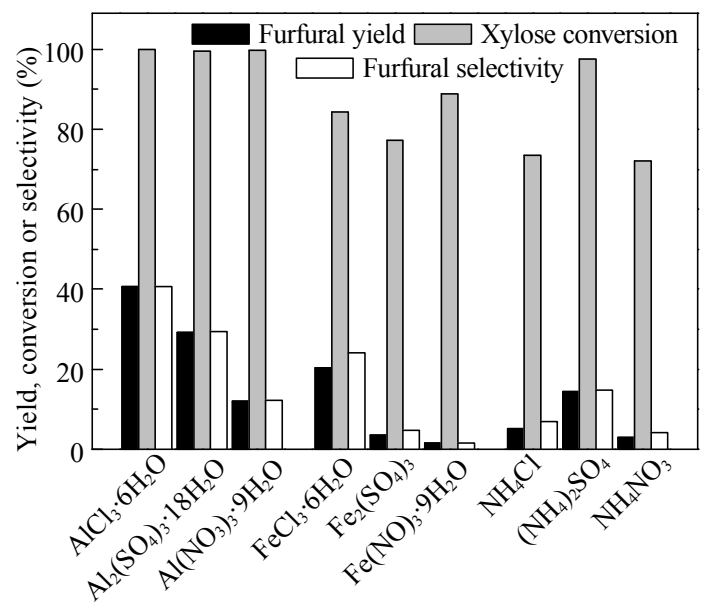

Fig. 1. Influence of anions in inorganic salts on the dehydration of xylose. Reaction conditions: $140{ }^{\circ} \mathrm{C}, 4 \mathrm{~h}$, solid to liquid ratio $1: 10$, catalyst/xylose molar ratio 0.5 . distillation in the conventional production process. Since then, more attention has been paid to the mechanism of furfural formation. It was confirmed that chlorides increased the reaction rate, in addition to enhancement of furfural separation by the salting-out effect [7]. Marcotullio et al. [22,23] reported that halides acted as weak bases, assisting enolization via proton transfer; they postulated that $\mathrm{Cl}^{-}$ions promoted the formation of the 1,2-enediol from the acyclic form of xylose, and accelerated the first and second dehydration steps, and the final intramolecular dehydration and ring closure, leading to furfural. However, the use of $\mathrm{NH}_{4} \mathrm{Cl}$ as the halide facilitated furfural production from xylose to a certain degree (Fig. 1). It was also found that the catalytic performance of $\left(\mathrm{NH}_{4}\right)_{2} \mathrm{SO}_{4}$ was higher than that of $\mathrm{NH}_{4} \mathrm{Cl}$ because of the significantly higher acidity of $\left(\mathrm{NH}_{4}\right)_{2} \mathrm{SO}_{4}$, which improves xylose conversion.

Stronger Lewis acids showed higher activity in the dehydration of xylose to furfural. Some metal chlorides act as Lewis acids, and $\mathrm{Cl}^{-}$ions have been proven to enhance furfural formation from D-xylose [22]. This result is confirmed by Fig. 1. The influences of different chlorides on the dehydration of xylose are shown in Fig. 2. Various metal chlorides, i.e., $\mathrm{CrCl}_{3}$, $\mathrm{CrCl}_{2}, \mathrm{FeCl}_{3}, \mathrm{SnCl}_{4}, \mathrm{AlCl}_{3}, \mathrm{LaCl}_{3}, \mathrm{CoCl}_{2}, \mathrm{NiCl}_{2}, \mathrm{CuCl}_{2}, \mathrm{ZnCl}_{2}$, and $\mathrm{NH}_{4} \mathrm{Cl}$, had positive impacts on xylose conversion compared with the non-catalytic process (Fig. 2). Among these metal chlorides, $\mathrm{SnCl}_{4}, \mathrm{AlCl}_{3}$, and $\mathrm{CrCl}_{3}$ exhibited superior catalytic activity in the dehydration of xylose at $140{ }^{\circ} \mathrm{C} ; \mathrm{SnCl}_{4}$ gave the highest catalytic performance, and achieved a maximum furfural yield of $48.9 \%$, with $52.2 \%$ of selectivity. $\mathrm{CrCl}_{2}$ and $\mathrm{FeCl}_{3}$ catalysts gave furfural yields of $22.3 \%$ and $20.4 \%$, respectively. $\mathrm{NiCl}_{2}, \mathrm{LaCl}_{3}, \mathrm{CoCl}_{2}, \mathrm{CuCl}_{2}, \mathrm{ZnCl}_{2}$, and $\mathrm{NH}_{4} \mathrm{Cl}$ catalysts resulted in low furfural yields, and it could that many other products were formed during the reaction. This showed that these inorganic salts had low selectivity for furfural, although the xylose conversion was higher than those in the absence of a catalyst. $\mathrm{LiCl}$, $\mathrm{NaCl}, \mathrm{KCl}, \mathrm{FeCl}_{2}, \mathrm{MgCl}_{2}, \mathrm{MnCl}_{2}$, and $\mathrm{CaCl}_{2}$ were found to be inefficient catalysts for furfural formation (data not shown in Fig. 2). Different chlorides therefore have different effects on the dehydration of xylose to furfural, based on their Lewis acid strengths.

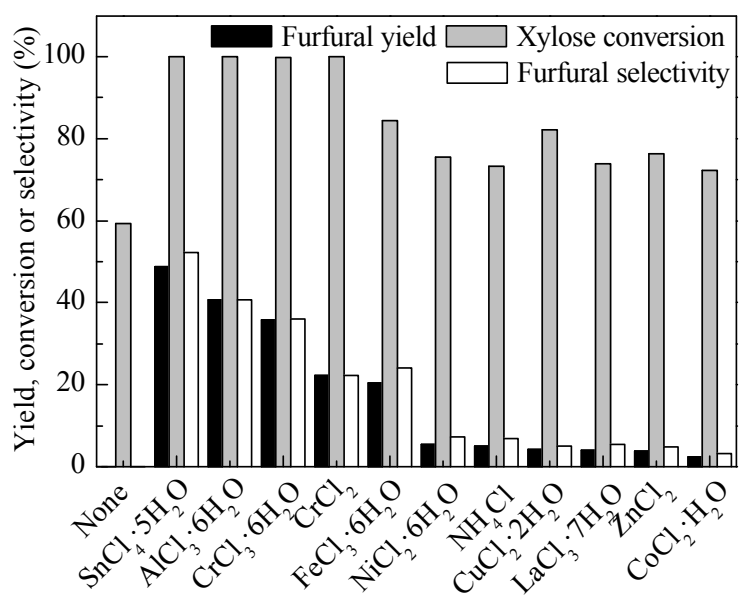

Fig. 2. Effects of different salts on the dehydration of xylose to furfural in $\mathrm{H}_{2} \mathrm{O}$ /DMSO system. Reaction conditions: $140{ }^{\circ} \mathrm{C}, 4 \mathrm{~h}$, solid to liquid ratio $1: 10$, catalyst/xylose molar ratio 0.5 . 
The main products in the conversion of xylose catalyzed by different inorganic salts were also investigated by GC-MS. The results showed that furfural was the main product with the catalysts and almost no product was found without catalyst, showing that $\mathrm{H}_{2} \mathrm{O}$ could not be ionized at low temperature to form the protons that enable the production of furfural from xylose. These results indicated that the inorganic salts investigated promoted furfural formation from D-xylose. Besides the main product furfural, there was one main by-product pyrrole-2-carboxaldehyde, which was found to be present when an inorganic salt (i.e., $\mathrm{NH}_{4} \mathrm{Cl},\left(\mathrm{NH}_{4}\right)_{2} \mathrm{SO}_{4}$ or $\mathrm{NH}_{4} \mathrm{NO}_{3}$ ) containing $\mathrm{NH}_{4}+$ ions was added to this system, indicating reaction of the nitrogen atoms in the $\mathrm{NH}_{4}{ }^{+}$ions with the intermediate products during the dehydration of xylose, forming new by-products.

\subsection{Effect of paired chloride catalysts on furfural yields}

As discussed above, $\mathrm{SnCl}_{4}$ gave better results than the other inorganic salts, and was thus used as a catalyst in the following work. Su et al. [14] found that mixtures of two metal chlorides, e.g., $\mathrm{CrCl}_{2} / \mathrm{CuCl}_{2}$, significantly improved the conversion of glucose. In this work, combinations of $\mathrm{SnCl}_{4}$ with other metal chlorides were used to investigate cooperation during homogeneous catalysis. $\mathrm{CrCl}_{3}, \mathrm{AlCl}_{3}, \mathrm{LiCl}, \mathrm{NaCl}$, and $\mathrm{KCl}$ were used as cocatalysts; their catalytic performance is shown in Fig. 3. When $\mathrm{SnCl}_{4}$ was used as the catalyst in the dehydration of xylose, the xylose conversion was greater than $98 \%$, so only furfural yields are given. Clearly, the furfural yield obtained with $\mathrm{SnCl}_{4} / \mathrm{LiCl}$ as the catalyst was higher than those obtained with other pairs or $\mathrm{SnCl}_{4}$ only. It is surprising that the less apparent decrease and the much obvious decrease in furfural yield using $\mathrm{SnCl}_{4} / \mathrm{CrCl}_{3}$ and $\mathrm{SnCl}_{4} / \mathrm{AlCl}_{3}$ paired catalysts, comparing to the single $\mathrm{SnCl}_{4}$, although $\mathrm{AlCl}_{3}$ and $\mathrm{CrCl}_{3}$ are strong Lewis acids. This indicates that $\mathrm{AlCl}_{3}$ and $\mathrm{CrCl}_{3}$ did not enhance the catalytic activity when mixed with $\mathrm{SnCl}_{4}$, whereas catalysts obtained by mixing $\mathrm{SnCl}_{4}$ and monovalent chlorides such as $\mathrm{LiCl}, \mathrm{NaCl}$, and $\mathrm{KCl}$ had higher catalytic activity. Among these monovalent chlorides, $\mathrm{LiCl}$ gave the best result. The cooperation between $\mathrm{SnCl}_{4}$ and $\mathrm{LiCl}$ afforded a furfural yield of $51.4 \%$. These results are consistent with that reported by Binder et al. [24], who found that $\mathrm{LiCl}$ and

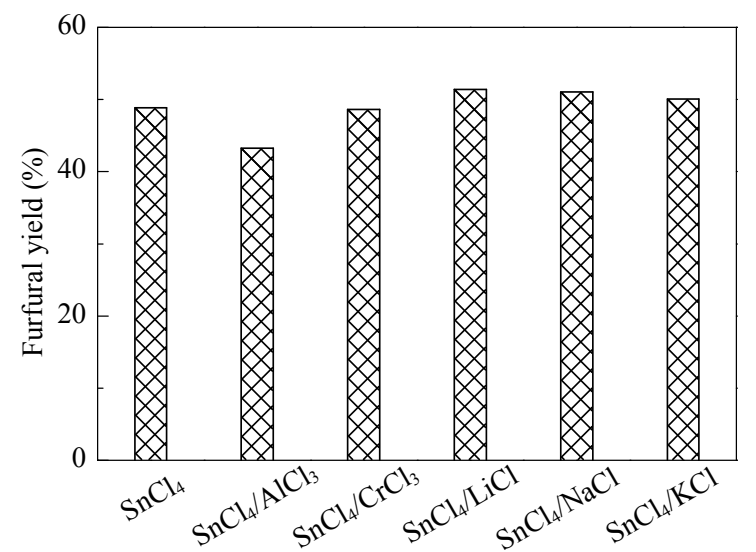

Fig. 3. Influence of different paired inorganic salts on furfural yields. Reaction conditions: $140{ }^{\circ} \mathrm{C}, 4 \mathrm{~h}$, solid to liquid ratio $1: 10$, catalyst/ xylose molar ratio 0.5 , the two chlorides molar ratio $1: 1$.
LiBr had high xylose conversion efficiency, giving 56\% furfural from xylose with $\mathrm{CrCl}_{2}$ (6 mol \%) in DMA containing 10 wt \% LiBr.

A series of experiments using $\mathrm{SnCl}_{4} / \mathrm{LiCl}$ with different $\mathrm{SnCl}_{4}$ molar ratios $\left(\chi_{\mathrm{SnCl} 4}\right)$ were conducted and the results are shown in Fig. 4. The yields of furfural consistently increased with increasing $\mathrm{SnCl}_{4}$ molar fraction. When $\chi_{\mathrm{SnCl} 4}$ reached 0.8 , the maximum furfural yield (56.9\%) was achieved, 8.0\% higher than that obtained using the single $\mathrm{SnCl}_{4}$ catalyst.

\subsection{Effect of $\mathrm{SnCl}_{4} / \mathrm{LiCl}$ catalyst/xylose molar ratio on furfural yield}

Experiments were carried out over $\mathrm{SnCl}_{4} / \mathrm{LiCl}\left(\chi_{\mathrm{SnCl} 4}=0.8\right)$ at $140{ }^{\circ} \mathrm{C}$ for $4 \mathrm{~h}$ to study the influence of the catalyst/xylose molar ratio on the furfural yield; the results are shown in Fig 5. With increasing reaction time, the yield of furfural first increased and then decreased. Larger amounts of insoluble solids were produced at longer time periods because the long residence time contributed to polymerization and oligomerization of furfural to give furanic resins; this decreased the pentose dehydration selectivity [25]. The results also showed that the catalyst amount had a significant effect on the furfural yield. For shorter time, the catalytic performance increased with increasing catalyst amount because of enhanced accessibility of the catalyst to xylose. A maximum furfural yield of $58.5 \%$ was

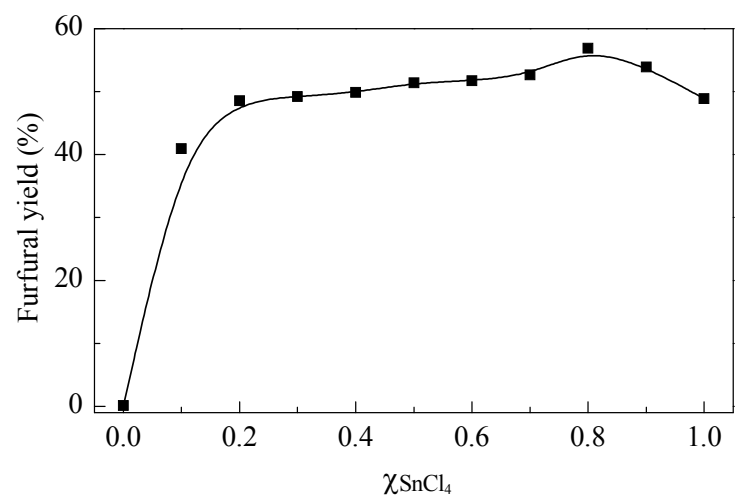

Fig. 4. Yield of furfural from xylose over paired $\mathrm{SnCl}_{4} / \mathrm{LiCl}$ catalyst with different $\mathrm{SnCl}_{4}$ molar fraction $\left(\chi_{\mathrm{SnCl}}\right)$. Reaction conditions: $140{ }^{\circ} \mathrm{C}, 4 \mathrm{~h}$, solid to liquid ratio 1:10, catalyst/xylose molar ratio 0.5 .

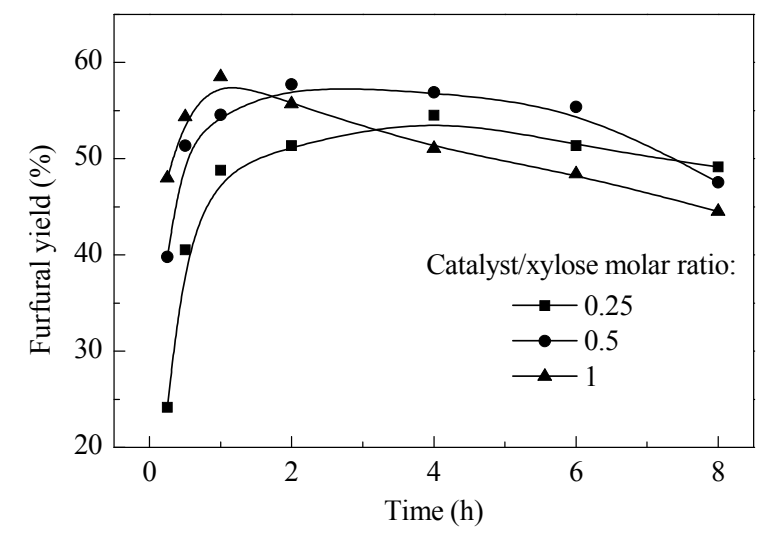

Fig. 5. Effect of $\mathrm{SnCl}_{4} / \mathrm{LiCl}$ catalyst/xylose molar ratio on furfural yield. Reaction conditions: $140^{\circ} \mathrm{C}$, solid to liquid ratio $1: 10$. 
obtained with a molar ratio of $1: 1$ at $140{ }^{\circ} \mathrm{C}$ for $1 \mathrm{~h}$. However, as well as increasing the cost, increasing the catalyst loading caused another problem, i.e., it favored side reactions, producing larger amounts of undesired by-products (seen in the vessel). For practical application, a reasonable ratio was $0.5: 1$ and a $57.7 \%$ yield of furfural was obtained within $2 \mathrm{~h}$.

\subsection{Effect of xylose content on furfural yield}

The influence of the xylose contents on the production of furfural was also studied; the results are shown in Fig. 6. In all cases, the furfural yields increased with increasing reaction time. The furfural yield sharply increased within $2 \mathrm{~h}$, indicating that most of the furfural was produced in a short time. For a solid to liquid ratio of $1: 30$, the furfural yield increased from $6.3 \%$ to $60.9 \%$ as the reaction time increased from 0.25 to $6 \mathrm{~h}$. Moreover, the furfural yield decreased when the time was further increased to over $6 \mathrm{~h}$, and the amount of insoluble solid residue increased as a result of formation of humins [26]. It was also found that with increasing xylose content, a shorter time was needed to reach the peak furfural yield, but the peak value decreased. This was probably because a higher content of xylose would increase the number of collisions between xylose and the catalyst, accelerating xylose conversion to furfural and leading to higher furfural yields. However, over a long period of time, the collisions also led to side reactions, decreasing the furfural yields. At a ratio of 1:20, the furfural yield (59.8\%) was relatively high at $140{ }^{\circ} \mathrm{C}$ for $4 \mathrm{~h}$. In view of the reaction rate of furfural production and energy consumption, a solid to liquid ratio of 1:20 was used in subsequent experiments.

\subsection{Effect of reaction temperature on furfural yield}

Experiments were carried out at different temperatures to study the temperature dependence of the furfural yield; the results are shown in Fig. 7. With increasing reaction temperature, the furfural yield sharply increased and the peak values were reached in shorter time. When the reaction time was further prolonged, the furfural yield gradually decreased, indicating that higher temperatures provided sufficient energy to promote side reactions, leading to the formation of soluble

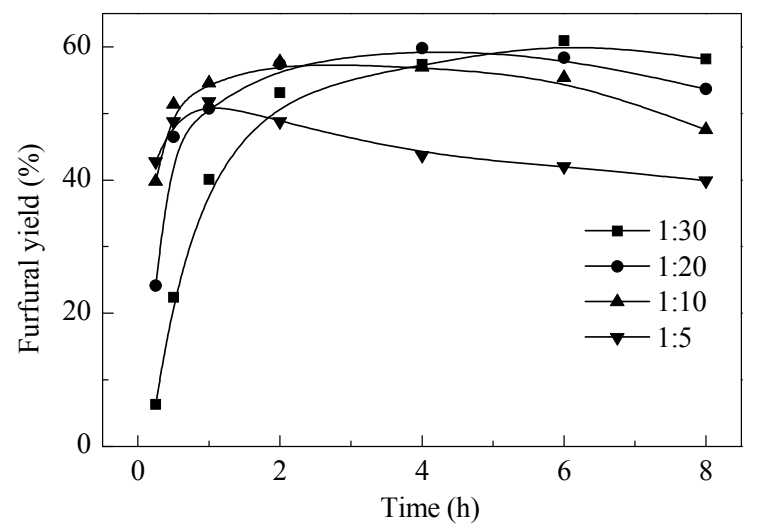

Fig. 6. Effect of xylose content on furfural yield. Reaction conditions: $140^{\circ} \mathrm{C}$, catalyst/xylose molar ratio 0.5 .

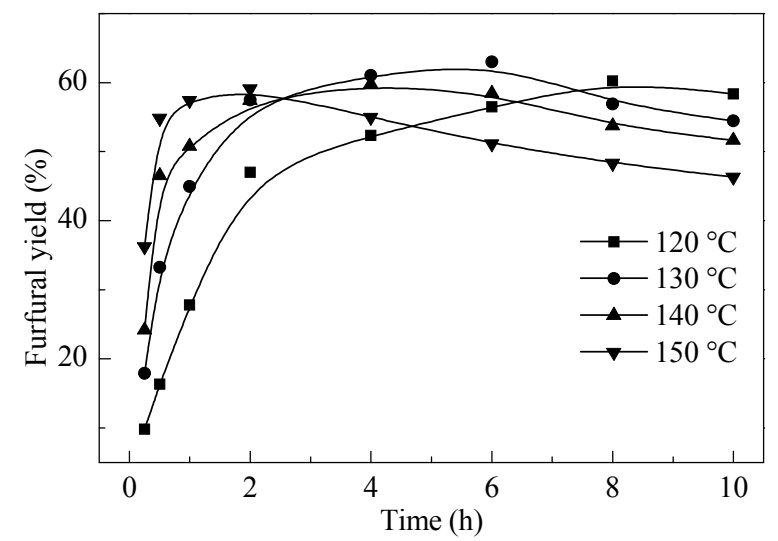

Fig. 7. Effect of reaction temperature and time on furfural yield. Reaction conditions: solid to liquid ratio 1:20, catalyst/xylose molar ratio 0.5 .

degradation products and black insoluble solids. A similar conclusion was drawn by O'Neill et al. [27]; they found that the stability of furfural at high temperatures was low, and furfural quickly formed degradation products. The optimal result for furfural formation in this work was achieved at $130{ }^{\circ} \mathrm{C}$ within 6 h, giving a maximum furfural yield of $63.0 \%$.

\subsection{Effect of DMSO content of $\mathrm{H}_{2} \mathrm{O} / \mathrm{DMSO}(\mathrm{V} / \mathrm{V})$ system on furfural yield}

DMSO has been proven to suppress side-reactions effectively and improve the selectivity [20]. In this study, DMSO was used as a cosolvent. The effect of the DMSO content in the $\mathrm{H}_{2} \mathrm{O} /$ DMSO mixture system on furfural production was investigated and the results are shown in Fig. 8. A system containing $\mathrm{H}_{2} \mathrm{O} /$ DMSO $=7 / 3(\mathrm{~V} / \mathrm{V})$ gave a furfural yield of $42.6 \%$, by $25 \%$ higher than that obtained without DMSO, but by $20 \%$ less than that obtained using a volume ratio of 5:5. It was observed that larger amounts of undesired insoluble solids were formed in the system without DMSO. These results showed that DMSO played a vital role in promoting furfural formation and significantly depressed side reactions. The results are consistent with the reported one [28].

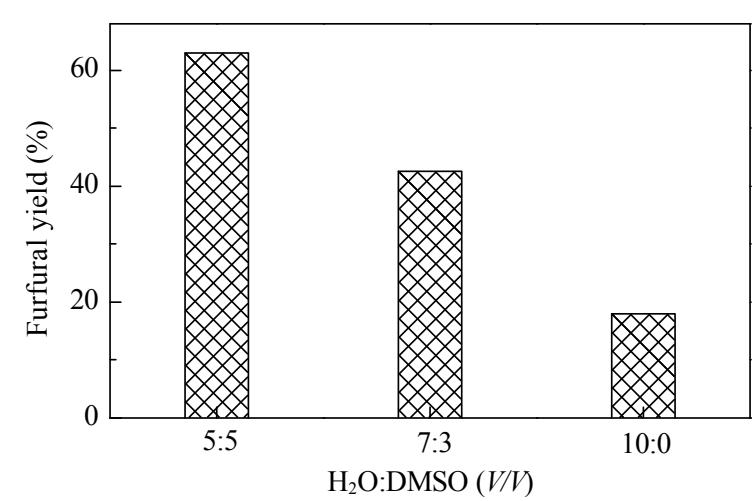

Fig. 8. Effect of $\mathrm{H}_{2} \mathrm{O} / \mathrm{DMSO}$ volume ratio on furfural yield. Reaction conditions: $130{ }^{\circ} \mathrm{C}, 6 \mathrm{~h}$, solid to liquid ratio $1: 20$, catalyst/xylose molar ratio 0.5 . 


\section{Conclusions}

An efficient and environmentally friendly process was developed for the dehydration of xylose to furfural using inorganic salts as catalysts in a homogeneous $\mathrm{H}_{2} \mathrm{O}$ /DMSO system at low temperature. The results showed that $\mathrm{SnCl}_{4}$ had high catalytic activity for the reaction. A paired $\mathrm{SnCl}_{4} / \mathrm{LiCl}$ catalyst $\left(\chi_{\mathrm{SnCl} 4}=\right.$ 0.8 ) was found to give the best catalytic performance. The highest furfural yield of $63.0 \%$ was obtained at $130{ }^{\circ} \mathrm{C}$ for $6 \mathrm{~h}$, with a catalyst/xylose molar ratio of 0.5 and a solid to liquid ratio of 1:20. The mechanism of xylose conversion to furfural using $\mathrm{SnCl}_{4} / \mathrm{LiCl}$ as catalysts will be investigated and microwave irradiation will be used to further improve the furfural yields.

\section{References}

[1] Zhang Z H, Zhao Z B K. Bioresour Technol, 2010, 101: 1111

[2] Hu S Q, Zhang Z F, Song J L, Zhou Y X, Han B X. Green Chem, 2009, 11: 1746

[3] Dutta S, De S, Saha B, Alam Md I. Catal Sci Technol, 2012, 2: 2025

[4] Binder J B, Raines R T. J Am Chem Soc, 2009, 131: 1979

[5] Sasaki M, Fang Z, Fukushima Y, Adschiri T, Arai K. Ind Eng Chem Res, 2000, 39: 2883

[6] Girisuta B, Janssen L P B M, Heeres H J. Chem Eng Res Des, 2006, 84: 339

[7] Zhang L X, Yu H B, Wang P, Dong H, Peng X H. Bioresour Technol, 2013, 130: 110

[8] Mao L Y, Zhang L, Gao N B, Li A M. Green Chem, 2013, 15: 727

[9] Lima S, Pillinger M, Valente A A. Catal Commun, 2008, 9: 2144

[10] Xing R, Qi W, Huber G W. Enery Environ Sci, 2011, 4: 2193
[11] Ferreira L R, Lima S, Neves P, Antunes M M, Rocha S M, Pillinger M, Portugal I, Valente A A. Chem Eng J, 2013, 215-216: 772

[12] Mamman A S, Lee J M, Kim Y C, Hwang I T, Park N J, Hwang Y K, Chang J S, Hwang J S. Biofuel, Bioprod Bioref-Biofpr, 2008, 2: 438

[13] Zhao H B, Holladay J E, Brown H, Zhang Z C. Science, 2007, 316: 1597

[14] Su Y, Brown H M, Huang X W, Zhou X D, Amonette J E, Zhang Z C. Appl Catal A, 2009, 361: 117

[15] Dutta S, De S, Saha B, Alam Md I, Abu-Omar M M, Saha B. J Catal, 2012, 288: 8

[16] Liu J P, Tang Y, Wu K G, Bi C F, Cui Q. Carbohydr Res, 2012, 350: 20

[17] vom Stein T, Grande P M, Leitner W, Domínguez de María P. ChemSusChem, 2011, 4: 1592

[18] Yang Y, Hu C W, Abu-Omar M M. ChemSusChem, 2012, 5: 405

[19] Hansen T S, Woodley J M, Riisager A. Carbohydr Res, 2009, 344: 2568

[20] Román-Leshkov Y, Chheda J N, Dumesic J A. Science, 2006, 312: 1933

[21] Dunlop A P, Peters F N. The Furans, ACS Monograph Series. New York: Reinhold Pub Corp, 1953

[22] Marcotullio G, de Jong W. Green Chem, 2010, 12: 1739

[23] Marcotullio G, de Jong W. Carbohydr Res, 2011, 346: 1291

[24] Binder J B, Blank J J, Cefali A V, Raines R T. ChemSusChem, 2010, 3: 1268

[25] Lessard J, Morin J F, Wehrung J F, Magnin D, Chornet E. Top Catal, 2010, 53: 1231

[26] Dias A S, Lima S, Pillinger M, Valente A A. Catal Lett, 2007, 114: 151

[27] O’Neill R, Ahmad M N, Vanoye L, Aiouache F. Ind Eng Chem Res, 2009, 48: 4300

[28] Rong C G, Ding X F, Zhu Y C, Li Y, Wang L L, Qu Y W, Ma X Y, Wang Z C. Carbohydr Res, 2012, 350: 77

\section{Graphical Abstract}

Chin. J. Catal., 2014, 35: 741-747 doi: 10.1016/S1872-2067(14)60031-0

\section{An efficient process for dehydration of xylose to furfural catalyzed by inorganic salt in water/dimethyl sulfoxide system}

Wenju Wang, Huiling Li, Junli Ren *, Runcang Sun, Jie Zheng, Guangwei Sun, Shijie Liu*

South China University of Technology; Beijing Forestry University; Dalian Polytechnic University

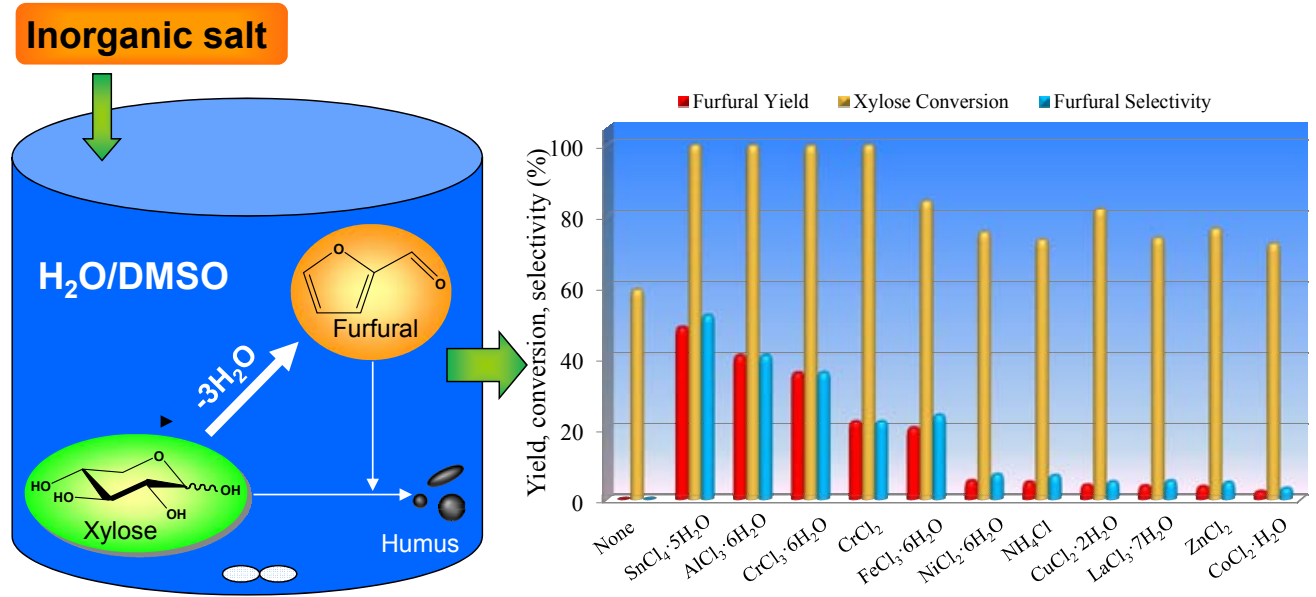

An efficient and environmentally friendly process is described for the dehydration of xylose to furfural using inorganic salts as catalysts in a homogeneous $\mathrm{H}_{2} \mathrm{O} /$ DMSO system under mild conditions. 


\section{水/二甲基亚砜体系中无机盐高效催化木糖脱水制备糠醛

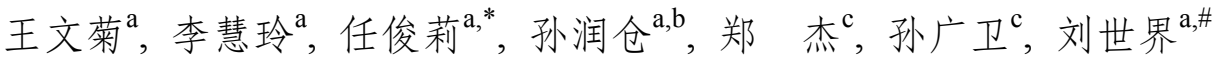 \\ 华南理工大学制浆造纸工程国家重点实验室, 广东广州510640 \\ ${ }^{\mathrm{b}}$ 北京林业大学生物质化学与技术研究所, 北京 100083 \\ ${ }^{\mathrm{c}}$ 大连工业大学辽宁省制浆造纸工程重点实验室, 辽宁大连116034}

摘要: 提出了一种高效的均相催化木糖制备糠醛的方法, 探讨了水/二甲基亚砜(DMSO)均相体系中不同类型的无机盐对催化木糖 制备糠醛的影响. 结果表明, 氯盐较硫酸盐和硝酸盐表现出较高的催化活性, 其中以 $\mathrm{SnCl}_{4}$ 的催化效果最高. 且它与 $\mathrm{LiCl}^{\text {复配时催 }}$ 化性能更高. 当 $\mathrm{SnCl}_{4}$ 的摩尔分数为 0.8 时, 催化效果最好, 糠醛收率达 $56.9 \%$. 反应条件优化实验发现, 当催化剂与木糖的摩尔比 为 $0.5: 1$, 固液比为 $1: 20$, 水与 DMSO体积比为 $5: 5$ 时, 于 $130{ }^{\circ} \mathrm{C}$ 下反应 $6 \mathrm{~h}$, 糠醛收率达 $63 \%$.

关键词: 木糖; 糠醛; 无机盐; 氯化锡; 氯化锂; 二甲基亚砜

收稿日期: 2014-01-07. 接受日期: 2014-01-13. 出版日期: 2014-05-20.

*通讯联系人. 电话: (020)87112009; 传真: (020)87111861; 电子信箱: renjunli@scut.edu.cn

通讯联系人. 电话/传真: (020)87111861; 电子信箱: sliu@esf.edu

基金来源：广东省自然科学杰出青年基金(S20120011250); 新世纪优秀人才支持计划(NCET-12-0194); 全国优博论文作者专项资 金(201169); 广东省科技计划项目(2011B050400015); 华南理工大学中央高校基本科研业务费专项资金(2014ZG0003).

本文的英文电子版由Elsevier出版社在ScienceDirect上出版(http://www.sciencedirect.com/science/journal/18722067). 